\title{
PENGARUH PENCAMPURAN TEPUNG KACANG MERAH (Phaseolus vulgaris) DAN TEPUNG TERIGU DENGAN PENAMBAHAN EKSTRAK UBI JALAR UNGU (Ipomoea batatas L.) TERHADAP SIFAT SENSORIS MIE KERING
}

\author{
Effect of Mixing Red Bean Flour (Phaseolus vulgaris) and Wheat Flour with Addition of \\ Purple Sweet Potato Extract (Ipomoea batatas L.) on Sensory Characteristics of Dry \\ Noodles
}

\author{
Bonita Siahaan $^{1)}$, Teltje Koapaha ${ }^{2)}$, dan Tineke Langi ${ }^{2)}$ \\ ${ }^{1)}$ Mahasiswa Program Studi Teknologi Pangan Unsrat \\ ${ }^{2)}$ Dosen Program Studi Ilmu dan Teknologi Pangan Unsrat \\ Jurusan Teknologi Pertanian Universitas Sam Ratulangi Manado \\ Jl. Kampus UNSRAT Manado, 95115. \\ *Email: bonita.siahaan@gmail.com
}

\begin{abstract}
The purpose of this study was to obtain the formulation of dry noodles with a mixture of red bean flour and wheat flour based on the level of acceptance. The statistical design of this experiment was a Completely Randomized Design (CRD) with treatments of the ratio of red bean flour and wheat flour i.e., A (20\% red bean flour : $80 \%$ wheat flour); B (40\% red bean flour : $60 \%$ wheat flour); C (60\% red bean flour : $40 \%$ wheat flour); D ( $80 \%$ red bean flour : $20 \%$ wheat flour). Each treatment was repeated 3 times. The results showed that dry noodles preferred by panelists based on color, flavor, and taste was A treatment (20\% red bean flour : $80 \%$ wheat flour) with the chemical composition and characteristics of that dry noodles was $4.83 \%$ water, $1.77 \%$ ash, $18.86 \%$ protein, $3.18 \%$ fat, $71.35 \%$ carbohydrates, 7.09 minutes of cooking time, $3.27 \%$ cooking loss, $73.20 \%$ swelling index, and $261.67 \%$ water absorption.
\end{abstract}

Keywords: dry noodles, red bean flour, purple sweet potato

\section{PENDAHULUAN}

Kacang merah (Phaseolus vulgaris) adalah salah satu jenis kacangkacangan yang memiliki kandungan protein dan serat tinggi. Kacang merah juga memiliki indeks glikemik yang rendah yaitu 26 (Farman, 2011). Kacang merah dapat tumbuh dengan baik dan mudah ditemukan di Sulawesi Utara. Di Sulawesi Utara, umumnya kacang merah diolah menjadi sup dan es. Selain diolah menjadi kedua produk tersebut, kacang merah juga dapat diolah menjadi tepung. Pengolahan kacang merah menjadi tepung dapat memperpanjang masa simpan kacang merah dan memudahkan proses pengolahan menjadi produk yang memiliki nilai ekonomi tinggi. Tepung kacang merah dapat digunakan sebagai campuran pada berbagai produk seperti roti, cookies, mie basah, dan mie kering. 
Mie kering adalah mie mentah yang dikukus dan dikeringkan, sehingga daya simpan mie lebih tahan lama bila dibandingkan dengan mie basah. Bahan dasar yang digunakan dalam pembuatan mie kering adalah tepung terigu.

Pembuatan mie kering dengan campuran tepung kacang merah dan tepung terigu dilakukan untuk meningkatkan pemanfaatan kacang merah sebagai bahan pangan lokal dan juga untuk mengurangi penggunaan tepung terigu. Untuk meningkatkan warna pada mie kering formulasi tepung kacang merah dan tepung terigu, maka ditambahkan ekstrak ubi jalar ungu. Selain itu, penelitian ini menggunakan ubi jalar ungu karena banyaknya jumlah ubi jalar ungu yang dijual di pasar tradisional ataupun di supermarket yang ada di Sulawesi Utara sehingga komoditas ini mudah untuk didapat. Tujuan penelitian ini adalah menentukan formula mie kering campuran tepung kacang merah dan tepung terigu yang tepat dan menganalisis sifat fisikokimia dan tingkat penerimaan panelis pada mie kering.

\section{METODE PENELITIAN}

Penelitian ini telah dilakukan di Laboratorium Teknologi Pangan Fakultas Pertanian Universitas Sam Ratulangi Manado, Laboratorium Aneka Komoditi BARISTAND Industri Manado, dan Laboratorium Farmasi Fakultas Matematika dan Ilmu Pengetahuan Alam Universitas Sam Ratulangi Manado selama kurang lebih 3 (tiga) bulan. Alat yang digunakan pada penelitian adalah, oven, penggiling/grinder, ayakan $80 \mathrm{mesh}$, noodle maker.. Bahan-bahan yang digunakan dalam penelitian ini tepung kacang merah, ekstrak ubi ungu, tepung terigu Bogasari: Cakra Kembar, telur, dan garam.

Penelitian ini menggunakan metode Rancangan Acak Lengkap (RAL) dengan perlakuan substitusi tepung kacang merah. Untuk masing-masing perlakuan dilakukan pengulangan sebanyak 3 (tiga) kali. Sehingga didapatkan perbandingan tepung kacang merah terhadap tepung terigu yaitu, A (20\% tepung kacang merah : $80 \%$ tepung terigu); B (40\% tepung kacang merah : $60 \%$ tepung terigu); C (60\% tepung kacang merah : $40 \%$ tepung terigu); D (80\% tepung kacang merah : $20 \%$ tepung terigu).

\section{Prosedur Kerja \\ Pembuatan Tepung Kacang Merah (Ekawati (1999) yang telah dimodifikasi)}

Proses pembuatan tepung kacang merah diawali dengan sortasi kacang merah. Selanjutnya kacang merah dicuci secara berulang dan direndam, kemudian tiriskan. Setelah itu kacang merah direbus selama 20 menit. Dilakukan pengeringan pada suhu $105^{\circ} \mathrm{C}$ selama 5 jam dalam oven. Selanjutnya giling atau hancurkan kacang merah dan ayak dengan menggunakan ayakan 80 mesh.

\section{Pembuatan Ekstrak Ubi Jalar Ungu (Sayuti (2013) yang telah dimodifikasi)}

Proses pembuatan ekstrak ubi jalar ungu diawali dengan mencuci ubi jalar ungu. Ubi jalar ungu dikupas dan dipotong di dalam baskom berisi air, guna menghilangkan getah yang melekat pada ubi jalar ungu. Ubi jalar ungu yang sudah dipotong-potong dimasukkan ke dalam mesin juicer untuk diambil ekstraknya. Setelah itu diamkan ekstrak ubi jalar ungu selama beberapa menit agar pati pada ubi jalar ungu mengendap. Selanjutnya pisahkan ekstrak ubi jalar ungu dari patinya.

\section{Pembuatan Mie Kering (Widyatmoko (2015) yang telah dimodifikasi) \\ Campurkan tepung terigu dan} tepung kacang merah sesuai perlakuan. Pada wadah lainnya, kocok telur dengan garam. Campurkan telur yang telah 
dikocok ke dalam campuran tepung terigu dan tepung kacang merah. Tambahkan ekstrak ubi ungu sedikit demi sedikit. Uleni hingga adonan tercampur. Adonan yang sudah tercampur dibentuk seperti lembaran, kemudian dilakukan pencetakan agar adonan membentuk untaian mie. Dilakukan pengukusan selama 10 menit dan didinginkan pada suhu kamar. Proses pengeringan dilakukan dengan oven bersuhu $125^{\circ} \mathrm{C}$ selama 3 jam.

\section{Prosedur Analisis}

\section{Uji Organoleptik (Metode Hedonik)}

Uji organoleptik dengan menggunakan metode hedonik yaitu uji tingkat kesukaan terhadap warna, aroma, dan rasa dari mie kering dengan menggunakan skala uji 1-5. Skala hedonik dapat diubah menjadi skala numerik dengan angka mutu menurut tingkat kesukaan (Sulistiyo, 2006). Terdapat 25 orang panelis yang menilai tingkat kesukaan terhadap mie kering dengan parameter yang dinilai yaitu warna, aroma, dan rasa dengan kategori : sangat tidak suka, tidak suka, netral, suka, dan sangat suka.

\section{HASIL DAN PEMBAHASAN}

\section{Tingkat Kesukaan Terhadap Warna}

Hasil pengujian organoleptik dengan metode hedonik terhadap warna mie kering berkisar antara $3.04-3.76$ (netral - suka). Hasil pengamatan tingkat kesukaan terhadap warna mie kering menunjukkan nilai rata-rata tingkat kesukaan panelis terhadap warna mie kering. Nilai teringgi terdapat pada mie kering yang dibuat dengan formulasi $20 \%$ tepung kacang merah dan $80 \%$ tepung terigu. Sedangkan nilai terendah diperoleh dari mie kering formulasi $80 \%$ tepung kacang merah dan $20 \%$ tepung terigu. Nilai rata-rata tingkat kesukaan terhadap warna mie kering dapat dilihat pada Tabel 1.
Tabel 1. Nilai Rata-rata Tingkat Kesukaan terhadap Warna Mie Kering

Perlakuan Rata-rata (\%) Notasi*

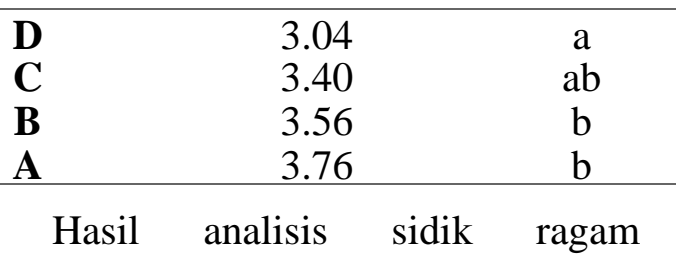

menunjukkan bahwa panelis rata-rata berada pada kategori netral - suka untuk warna dari mie kering. Warna mie kering yang dihasilkan yaitu ungu tua. Hal ini disebabkan oleh penggunaan ekstrak ubi jalar ungu yang mana ubi jalar ungu memiliki pigmen antosianin.

Uji BNT 5\% menunjukkan bahwa perlakuan A (20\% tepung kacang merah : $80 \%$ tepung terigu) dan perlakuan B (40\% tepung kacang merah : $60 \%$ tepung terigu) tidak berbeda nyata terhadap perlakuan $\mathrm{C}$ (60\% tepung kacang merah : 80\% tepung terigu), namun berbeda sangat nyata terhadap perlakuan D (80\% tepung kacang merah : $20 \%$ tepung terigu). Hasil analisis memperlihatkan bahwa semakin meningkat rasio tepung kacang merah, maka tingkat kesukaan panelis terhadap warna mie kering akan semakin rendah. Hal ini diduga karena semakin meningkat substitusi tepung kacang merah, warna dari mie kering menjadi semakin gelap karena adanya kandungan antosianin pada kacang merah (Cahyani, 2011).

\section{Tingkat Kesukaan Terhadap Aroma}

Aroma merupakan faktor yang sangat penting untuk menentukan tingkat penerimaan konsumen terhadap suatu produk. Hasil pengujian organoleptik dengan metode hedonik terhadap aroma mie kering berkisar antara $3.20-3.76$ (netral - suka). Hasil pengamatan tingkat kesukaan terhadap aroma mie kering menunjukkan nilai rata-rata tingkat kesukaan panelis terhadap aroma mie kering. Nilai teringgi terdapat pada mie kering yang dibuat dengan formulasi $20 \%$ tepung kacang merah dan $80 \%$ tepung 
terigu. Sedangkan nilai terendah diperoleh dari mie kering formulasi $80 \%$ tepung kacang merah dan $20 \%$ tepung terigu.

Tabel 2. Nilai rata-rata tingkat kesukaan terhadap aroma mie kering

\begin{tabular}{ccc}
\hline Perlakuan & $\begin{array}{c}\text { Rata-rata } \\
(\boldsymbol{\%})\end{array}$ & Notasi* \\
\hline D & 3.20 & $\mathrm{a}$ \\
C & 3.20 & $\mathrm{a}$ \\
B & 3.28 & $\mathrm{a}$ \\
A & 3.76 & $\mathrm{~b}$ \\
\hline
\end{tabular}

Hasil analisis sidik ragam menunjukkan bahwa panelis rata-rata berada pada kategori netral - suka untuk aroma dari mie kering. Uji BNT 5\% menunjukkan bahwa perlakuan A $(20 \%$ tepung kacang merah : $80 \%$ tepung terigu), perlakuan B ( $40 \%$ tepung kacang merah : $60 \%$ tepung terigu), dan perlakuan C $(60 \%$ tepung kacang merah : $80 \%$ tepung terigu) tidak berbeda nyata, tetapi berbeda sangat nyata terhadap perlakuan D (80\% tepung kacang merah : $20 \%$ tepung terigu).

Hasil analisis memperlihatkan bahwa semakin meningkat rasio tepung kacang merah, maka tingkat kesukaan panelis terhadap aroma mie kering akan semakin rendah. Hal ini dikarenakan tingginya bau langu pada kacang merah yang mengakibatkan produk akhir menjadi kurang diterima masyarakat (Yodatama, 2011).

\section{Tingkat Kesukaan Terhadap Rasa}

Hasil pengujian organoleptik dengan metode hedonik terhadap rasa mie kering berkisar antara 2.86-4.02 (netral suka). Hasil pengamatan tingkat kesukaan terhadap rasa mie kering menunjukkan nilai rata-rata tingkat kesukaan panelis terhadap rasa mie kering. Nilai tertinggi terdapat pada mie kering yang dibuat dengan formulasi 20\% tepung kacang merah dan $80 \%$ tepung terigu. Sedangkan nilai terendah diperoleh dari mie kering formulasi $80 \%$ tepung kacang merah dan $20 \%$ tepung terigu.

Tabel 3. Nilai rata-rata tingkat kesukaan terhadap rasa mie kering

\begin{tabular}{ccc}
\hline Perlakuan & $\begin{array}{c}\text { Rata-rata } \\
(\boldsymbol{\%})\end{array}$ & Notasi* \\
\hline D & 2.36 & $\mathrm{a}$ \\
C & 2.92 & $\mathrm{ab}$ \\
B & 3.08 & $\mathrm{~b}$ \\
A & 3.52 & $\mathrm{~b}$ \\
\hline Hasil & analisis sidik & ragam
\end{tabular}

menunjukkan bahwa panelis rata-rata berada pada kategori netral - suka untuk rasa dari mie kering. Uji BNT $1 \%$ menunjukkan bahwa perlakuan A $(20 \%$ tepung kacang merah : $80 \%$ tepung terigu) dan perlakuan B (40\% tepung kacang merah : $60 \%$ tepung terigu) tidak berbeda nyata terhadap perlakuan $\mathrm{C}(60 \%$ tepung kacang merah : $80 \%$ tepung terigu), namun berbeda sangat nyata terhadap perlakuan D (80\% tepung kacang merah : $20 \%$ tepung terigu). Hasil analisis memperlihatkan bahwa semakin meningkat rasio tepung kacang merah, maka tingkat kesukaan panelis terhadap rasa mie kering akan semakin rendah. Hal ini diduga karena adanya rasa getir pada kandungan kacang merah (Ekawati, 1999).

Dari uji organoleptik didapat bahwa perlakuan yang terbaik adalah formulasi tepung kacang merah $20 \%$ dan tepung terigu $80 \%$. Maka dari itu dilanjutkan dengan uji komposisi kimia dengan hasil dapat dilihat pada table 4.

Tabel 4. Komposisi kimia perlakuan terbaik

\begin{tabular}{clc} 
No. & Komposisi Kimia & Rata-rata $(\%)$ \\
\hline 1. & Kadar Air & 4.83 \\
2. & Kadar Abu & 1.77 \\
3. & Kadar Protein & 18.86 \\
4. & Kadar Lemak & 3.18 \\
5. & Kadar Serat Kasar & 2.16 \\
6. & Total Karbohidrat & 71.35
\end{tabular}




\section{KESIMPULAN}

Dari hasil penelitian ini dapat disimpulkan bahwa formulasi mie kering dengan tepung kacang merah $20 \%$ dan tepung terigu $80 \%$ adalah yang paling disukai panelis, baik dari warna, aroma, maupun rasa, dengan kadar air $4.83 \%$, kadar abu $1.77 \%$, kadar protein $18.86 \%$, kadar lemak $3.18 \%$, kadar serat kasar $2.16 \%$, dan total karbohidrat $71.35 \%$.

\section{DAFTAR PUSTAKA}

Cahyani, K. 2011. Kajian Kacang Merah (Phaseolus vulgaris) sebagai Bahan Pengikat dan Pengisi pada Sosis Ikan Lele. Skripsi. Universitas Sebelas Maret Surakarta.

Ekawati, D. 1999. Pembuatan Cookies dari Tepung Kacang Merah (Phaseolus vulgaris L) sebagai Makanan Pendamping Asi (MPASI). Skripsi. Institut Pertanian Bogor.

Farman, S. 2011. Pengaruh Pemberian Ekstrak Kacang Merah Terhadap Penurunan Kadar Glukosa Darah Tikus Wistar Jantan yang Diberi Beban Glukosa. Skripsi. Universitas Diponegoro.

Hardoko., L. Hendarto, dan T. M. Siregar. 2010. Pemanfaatan Ubi Jalar Ungu (Ipomoea Batatas L.) Sebagai Pengganti Sebagian Tepung Terigu dan Sumber Antioksidan pada Roti Tawar. Jurnal Teknologi dan Industri Pangan 21(1): 25-32.

Kaushal, P dan H. K. Sharma. 2013. Convective Dehydration Kinetics of Noodles Prepared from Taro (Colocasia esculenta), Rice (Oryza sativa) and Pigeonpea (Cajanus cajan) Flours. Journal of Agriculture Engineering International CIGR. 15 (4): 202212.
Khoiri, A. 2013. Sifat Tekstural dan Cooking Quality Mi Bebas Gluten dari Tepung Sukun. Seminar Nasional: Menggagas Kebangkitan Komoditas Unggulan Lokal Pertanian dan Kelautan. Madura

Oh, N. H., P. A. Seib, and D. S. Chung. 1985. Noodles III. Effects of Processing Variables on The Quality Characteristic of Dry Noodles. Cereal Chem. 62(6): 437-440.

Sayuti, I., S. Wulandari, dan D. Sari. 2013. Penambahan Ekstrak Ubi Jalar Ungu (Ipomoea batatas var Ayamurasaki) dan Susu Skim Terhadap Organoleptik Yoghurt Jagung Manis (Zea mays L. Saccharata) dengan Menggunakan Inokulum Lactobacillus acidophilus dan Bifidobacterium sp. Prosiding Semirata FMIPA Universitas Lampung, Lampung. Hal. 399-410.

Sulistiyo, C. 2006. Pengembangan Brownies Kukus Tepung Ubi Jalar (Ipomoea Batatas) di PT. FITS Mandiri Bogor. Skripsi. Institut Pertanian Bogor.

Widiatmoko, R dan T. Estiasih, 2015. Karakteristik Fisikokimia dan Organoleptik Mie Kering Berbasis Tepung Ubi Jalar Ungu pada Berbagai Tingkat Penambahan Gluten. Jurnal Pangan dan Agroindustri. 3(4): 1386-1392.

Yodatama, K. 2011. Perencanaan Unit Pengolahan "Brownies" Kacang Merah (Phaseolus vulgaris) Skala Industri Kecil. Skripsi. Universitas Brawijaya Malang. 